\title{
Abbreviations
}

AFPFL Anti-Fascist People’s Freedom League

AFL American Federation of Labor

AMPP

ASEAN Motion Picture Producers Association

APEC

Asia-Pacific Economic Cooperation

ASEAN

Association of Southeast Asian Nations

CCF

Congress for Cultural Freedom

CEPA

Closer Economic Partnership Arrangement

CFA

Committee for a Free Asia

CFE Committee for a Free Europe

CIE Civil Information and Education Section

CMPC Central Motion Picture Corporation

CMPE Central Motion Picture Exchange

DPRK Democratic People's Republic of Korea (North Korea)

ECA Economic Cooperation Administration

ECAFE Economic Commission of Asia and the Far East

ECOSOC United Nations Economic and Social Council 
ESA

Economic Stabilization Agency

FPA

Federation of Motion Picture Producers in Southeast Asia

GMP

Grand Motion Picture Company

HICOG

US High Commissioner for Germany

HIFF

Hawaii International Film Festival

ICC

East West Center's Institute of Culture and Communication

IFFI

International Film Festival of India

IFFPA

International Federation of Film Producers Association

KMPPA Korean Motion Picture Producer's Association

KMPCA

Korean Motion Picture Cultural Association

MPAA

Motion Picture Association of America

MPEA

Motion Picture Export Association

MP\&GI

Motion Picture and General Investment

MPPDA

Motion Picture Producers and Distributors of America

NATO

North Atlantic Treaty Organization

OPC

Office of Policy Coordination

OSS

Office of Strategic Services

PRC

People’s Republic of China

RFA

Radio Free Asia

RFE

Radio Free Europe

ROK

Republic of Korea

SEATO

Southeast Asia Treaty Organization

SFIFF

San Francisco International Film Festival

SWG

Screen Writers Guild

TAF

The Asia Foundation

TCA

Technical Cooperation Administration

UNKRA

United Nations Korean Reconstruction Agency

USIA United States Information Agency

USIS United States Information Service

VOA Voice of America

WBC World Buddhist Congress

WFB World Fellowship of Buddhists 


\section{CINEMA AND THE CULTURAL COLD WAR}


